\title{
Costimulation and $\mathrm{T}$ cells as therapeutic targets
}

\author{
Alison M. Gizinski, MD ${ }^{1}$, David A. Fox, MD ${ }^{1}$, and Sujata Sarkar, MD \\ Alison M. Gizinski: agizinsk@med.umich.edu; David A. Fox: dfox@med.umich.edu \\ ${ }^{1}$ Division of Rheumatology, Department of Internal Medicine and Rheumatic Disease Core \\ Center, University of Michigan, 1500 East Medical Center Drice, 3918 Taubman Center, SPC \\ 5358, Ann Arbor, Michigan 48109, USA, Phone: 734 936-5560, Fax: 734 763-1253 \\ 2 Section of Rheumatology, Department of Medicine, University of Arizona, 1501 North Campbell \\ Avenue, Rm 6310, Tucson, Arizona, 85724, USA
}

\begin{abstract}
Full activation and differentiation of resting $\mathrm{T}$ cells into effector $\mathrm{T}$ cells requires at least two signals, the first through engagement of the T cell antigen receptor (TCR) by the antigen-MHC complex on antigen presenting cells (APC), and the second by engagement of co-stimulatory molecules such as CD28, on T cells by ligands such as CD80/86 on APCs. Effector T cell differentiation is associated with proliferation, secretion of cytokines, and expression of additional surface molecules. These inducible structures may have stimulatory (ICOS, OX40, and 4-1BB) or inhibitory (CTLA-4) potential. To the extent that $\mathrm{T}$ cells have a role in particular immunemediated diseases, interruption of $\mathrm{T}$ cell co-stimulation is a potentially worthwhile approach to treatment of those conditions. This article summarizes experience in treating rheumatological disease by perturbation of $\mathrm{T}$ cell co-stimulation, and also describes structures that could be future targets for this type of therapeutic approach.
\end{abstract}

\section{CD28:CTLA-4 (CD152)/CD80:CD86}

CD28 is the prototypic TCR for co-stimulatory signals. CTLA-4, which is up-regulated on activated T cells, also binds to the CD28 ligands CD80/86 (B7.1 and B7.2), and this interaction inhibits further $\mathrm{T}$ cell activation (1-4).

The ligation of CD28 by CD80/86 not only sends co-stimulatory signals into the $\mathrm{T}$ cell but can also send activating signals into the APC (5). Maturation and activation of APCs is accompanied by expression of other co-stimulatory molecules, as well as secretion of cytokines such as IL-6. Induction of IL-6 secretion from APCs via CD80/86 is of interest since IL-6 is one of the cytokines associated with the pathogenesis of rheumatoid arthritis (RA). IL-6 is necessary for the development of Th17 cells, which contribute to several autoimmune diseases including RA, and IL-6 also has downstream roles in tissue damage. This is only one example of the many ways in which co-stimulatory receptor-ligand engagement is linked to cytokine pathways in RA and other diseases. Therapeutic blockade of such interactions would be expected, therefore, to have secondary effects on key diseaserelated cytokines.

In addition to interfering with the binding of CD28 to CD80/86, thereby interrupting the costimulatory signal into T cells via CD28, CTLA- 4 can also send inhibitory signals directly into the $\mathrm{T}$ cell that further limit $\mathrm{T}$ cell activation $(6,7)$. Likewise, the ligation of $\mathrm{CD} 80 / 86$ by CTLA-4 can also deliver regulatory signals to the APC. The interaction of CD80/86 with 
CTLA-4 leads to the induction of indoleamine dioxygenase (IDO) in APCs. IDO is thought to be critical in inducing anergy in T cells, during the T cell-APC interaction, via the depletion of tryptophan, which is necessary for full $\mathrm{T}$ cell activation $(8,9)$. These findings suggest that CTLA- 4 can actively dampen $\mathrm{T}$ cell activation both by direct effects on the $\mathrm{T}$ cell and also by effects on APCs.

Thus, the interaction of CD28 with CD80/CD86 is critical in the regulation of $\mathrm{T}$ cell activation and is an important target in autoimmune diseases associated with aberrant activation of T cells such as RA. However, use of antibodies against CD28 itself would be hazardous if agonistic effects occurred. Indeed, administration of TGN1412, an anti-CD28 monoclonal antibody, to healthy human volunteers resulted in acute onset of cytokine storm and associated multi-organ failure (10). This led to suspension of further development of this drug or of other antibodies directly targeting CD28.

CTLA-4Ig which is composed of CTLA-4 fused with the constant portion of the human IgG, binds to CD80/CD86 on APCs and thereby interferes with the co-stimulation of T cells induced by the interaction of CD80/CD86 with CD28. CTLA-4Ig was developed as a therapeutic intervention for RA and transplant rejection, two diseases associated with $\mathrm{T}$ cell activation. Preclinical studies with CTLA-4Ig showed promise in an animal model of RA (11). CTLA-4Ig (abatacept) was approved for treatment of RA in 2007.

\section{Clinical studies of CTLA-4lg (abatacept) in RA}

After a successful Phase I study where 50\% of the patients achieved ACR 20 responses without any significant adverse events, a phase II study was done in patients with active disease despite standard doses of methotrexate. In this study, abatacept was administered concurrently with stable doses of methotrexate for 6 months. The ACR 20/50/70 responses were $60 \%, 36 \%$, and $16 \%$ in the group receiving abatacept plus methotrexate compared to $25 \%, 12 \%$, and $2 \%$ in the placebo plus methotrexate arm $(12,13)$. The patients in this trial continued to improve beyond the initial 6 month period, in an open label extension trial with abatacept and methotrexate for additional 6 months. The percentage of patients achieving ACR50 and ACR70 increased to $41.7 \%$ and $20.9 \%$ respectively (14). The same cohort of patients continued to show improvement in clinical efficacy with an acceptable safety profile in a 5 year extension study. The ACR20/50/70 responses at 5 years were $82.7 \%$, $65.4 \%$, and $40 \%$ respectively (15).

The Abatacept Trial in Treatment of Anti-TNF Inadequate Responders (ATTAIN), a 6 month phase III trial, was done in patients with RA who had inadequate clinical response or adverse effects on anti-TNF agents (16). A significant proportion of patients demonstrated a favorable therapeutic response at 6 months. The percentage of patients achieving ACR20/50/70 responses were 50\%, 20.3\%, and $10.2 \%$ in the study arm, in comparison to $19.5 \%, 3.8 \%$, and $1.5 \%$ in the placebo arm. This study was then continued as an open label extension for additional 18 months with continued improvement, with 56\% achieving ACR20, 33\% achieving ACR50, and 16\% achieving ACR70 responses (17). These findings were confirmed in another trial involving patients with inadequate responses to anti-TNF agents. This study showed that a washout period, in previous anti-TNF non-responders, was not necessary for subsequent improvement with abatacept (18).

The sustained clinical efficacy of abatacept was shown in another trial in which abatacept was administered to patients who had inadequate responses to methotrexate, Abatacept in Inadequate Responders to Methotrexate (AIM) (19). This study was designed to evaluate clinical improvement as well as radiographic progression. In this 1 year study patients continued to show clinical improvement similar to previous studies with ACR 20/50/70 responses being $73 \%, 48.3 \%$ and $28.8 \%$, in comparison to $39.7 \%, 18.2 \%$ and $6 / 1 \%$ in the 
placebo group, respectively. Further, there was a 50\% reduction in the progression of the Genant Modified Sharp scores in the abatacept group. As in the previous studies, patients in this study were continued for an additional 12 months in an open label extension study. There was continued clinical and radiographic improvement into the end of the second year.

Abatacept was directly compared with infliximab or placebo in the Tolerability, Efficacy and Safety in Treating Rheumatoid Arthritis (ATTEST) trial. This 12 month study demonstrated that patients treated with infliximab had more rapid clinical improvement than patients on abatacept during the initial 6 months, but patients on abatacept continued to have the same rate of clinical response throughout the 1 year period of the study and the clinical response at 1 year was therefore significantly greater than in the infliximab group (DAS28 scores changed by -2.88 in the abatacept group vs -2.25 in the infliximab group) (18). It is important to point out that while abatacept was used at $10 \mathrm{mg} / \mathrm{kg}$, which is the optimal dosage used in clinical practice, infliximab was used at $3 \mathrm{mg} / \mathrm{kg}$, which is on the lower end of the recommended dosage of $2 \mathrm{mg} / \mathrm{kg}-8 \mathrm{mg} / \mathrm{kg}$. The therapeutic efficacy of abatacept in comparison to higher dosages of infliximab or to other anti-TNF agents remains to be evaluated. In a recent study, involving patients with early RA, administration of abatacept in combination with methotrexate was associated with a significantly increased rate of remission compared to administration of methotrexate alone, at 1 year of follow up. Fortyone percent in the abatacept plus methotrexate group achieved DAS28 defined remission (DAS28<2.6) compared to $23.3 \%$ in the methotrexate only group (22).

Abatacept demonstrated a favorable safety profile in all of the above trials. Two trials were designed to assess the safety of abatacept in combination with other agents. The Abatacept Study of Safety in Use with other RA Therapies (ASSURE) trial was designed to evaluate the safety of abatacept for use in patients receiving DMARDS, as well as biologics (23). Patients receiving abatacept along with other non-biologic DMARDS demonstrated a favorable safety profile. On the other hand, combination of abatacept with other biologics was associated with an increased rate of infections (23). In another trial abatacept was administered along with etanercept (24). Patients on the combination did not show significant clinical improvement over and above those treated with a single biologic agent, but had more infections. These studies demonstrate that abatacept has a favorable safety profile when administered with non-biologic DMARDS, but the combination of abatacept with another biologic agent is not recommended.

The above studies illustrate the efficacy of abatacept in the treatment of RA, in various scenarios including early RA, methotrexate non-responders, and anti-TNF failures. Additionally it has been shown to be consistently safe in multiple studies, except in combination with other biologic agents.

Although CTLA-4Ig (abatacept) was developed to reduce the activating signal into the T cell via CD28, the precise mechanisms of action underlying the therapeutic response in RA remain to be elucidated. In one study serum IL-6 was reduced in RA patients on CTLA-4Ig, suggesting that interruption of the activation/maturation signal into APCs via CD80/86 might be important (25). In another study, levels of IFN- $\gamma$, IL-6, IL-1 $\beta$, and MMPs were reduced in the RA synovium of patients receiving abatacept. In the same patients, the levels of RANK/RANKL, which interact to induce osteoclastogenesis, were lowered, while OPG (osteoprotegerin), a decoy receptor which inhibits bone damage by interfering with RANK/ RANKL, tended to increase (26). Thus it is possible that abatacept has direct as well as indirect effect on both $\mathrm{T}$ cells and other immune system cells in RA. 


\section{Belatacept - a modified CTLA-4Ig}

Belatacept, the second generation modified version of abatacept, is composed of an altered extracellular domain of CTLA-4 fused to an altered Fc portion of human IgG. The Fc portion contains two mutations that reduce its ability to bind to Fc receptors. The CTLA-4 component of belatacept bears two mutations that increase binding affinity to CD80 and CD86. Belatacept binds to both CD80 and CD86, but with a greater affinity for CD80. However the binding to both CD80 and CD86 on APCs is required for the full suppressive effect of belatacept $(27,28)$. This drug has shown promise in clinical trials in renal transplantation (29). A phase II trial has been completed in RA and results are pending (NCT00279760).

\section{OX40 (CD134)/OX40L (CD252)}

OX40 is predominantly expressed on activated CD4 and CD8 T cells, following stimulation via TCR and CD28, and its ligand, OX40L is expressed on dendritic cells, B cells, macrophages, and endothelial cells. (30). Pro-inflammatory cytokines IL-1, IL-2 and TNF can further augment the expression of OX40. OX40L is induced on APCs after stimulation via Toll Like Receptors as well as CD40 $(31,32)$. There is bidirectional activation of T cells and APCs via the OX40-OX40L pathway. Stimulation of OX40 on T cell induces proliferation and cytokine secretion and signaling via OX40L into APCs induces the secretion of pro-inflammatory cytokines by the APCs. (31). Targeting of this interaction with anti-OX40L antibody or liposomes coated with anti-OX40 antibody has been shown to reduce severity of arthritis in animal models of RA (33-35).

In RA there is increased expression of OX40 on peripheral blood CD4 T cells with a trend towards a positive correlation with serum CRP levels. OX40 as well as OX40L expressing cells are also present in increased numbers in RA synovium. OX40 is expressed on both CD4 and CD8 positive synovial T cells, and the levels of expression correlate with disease activity $(34,36-38)$.

The interaction of OX40 with OX40L is important in RA in the context of T cell interactions with endothelial cells as well as B cells. Ligation of OX40 on activated T cells by OX40L on endothelial cells is thought to facilitate egress of activated T cells from the peripheral circulation into the target tissue (39), while ligation of OX40 by OX40L on B cells induces proliferation and immunoglobulin secretion by the B cells $(40,41)$.

Although there is increased expression of OX40 and OX40L in RA synovium, and preclinical studies in animal models, involving abrogation of this interaction, have shown promise, much remains to be elucidated regarding the role of OX40/OX40L in mediating immune events underlying RA. Currently there is an ongoing phase II trial involving antiOX40L antibody in patients with asthma (NCT00983658).

\section{ICOS (CD278)/ICOSL (CD275)}

ICOS/ICOSL belongs to the CD28 family of co-stimulatory molecules. ICOS is predominantly expressed on CD4 and CD8 T cells following activation by CD28. ICOSL is predominantly expressed on B cells. Studies in mice as well as in humans have shown that ICOS signaling into the T cells induces IL-4 and IL-10 secretion from T cells.

ICOS deficient mice have attenuated $\operatorname{IgM}$ and $\operatorname{IgG}$ responses, as well as reduced levels of the inflammatory cytokine IL-17, and are resistant to inflammatory arthritis, suggesting that this pair can also mediate bi-directional signaling, into the B cell as well as the T cell (42). In keeping with this finding, administration of anti-ICOSL antibody resulted in attenuation 
of CIA with associated reduction in anti-collagen antibody responses and reduced production of pro-inflammatory cytokines TNFa, IL-1, and IL-6 (43).

ICOS expression is increased on CD4 memory T cells in the synovial fluid and ICOSL is expressed in the synovial tissue in RA. Stimulation of the synovial fluid T cells via ICOS is associated with increased cytokine production $(44,45)$. Monocytes from RA synovial fluid have augmented expression of ICOSL as well as ICOS (45). Binding of ICOSL on monocytes to ICOS on T cells, within the inflamed joint, could provide costimulatory signals to the T cells. Efficacy of blocking ICOS-ICOSL interactions in RA remains to be established, but an anti-ICOSL antibody is currently undergoing a phase I trial in patients with SLE (NCT00774943).

\section{4-1BB (CD137)/4-1BBL(CD137L)}

4-1BB is induced on CD4 and CD8 T cells following stimulation via the TCR and CD28. The ligand for 4-1BB, 4-1BBL is expressed on activated B cells, dendritic cells and macrophages. Additionally, under certain circumstances dendritic cells express 4-1BB and T cells express the 4-1BBL (46).

The functional consequences of ligation of this pair are complex. The duration of expression of these molecules can be transient or sustained, depending on the cell type and the immune microenvironment. The effects of signaling via 4-1BB into CD4 T cells are distinct from signaling into $\mathrm{CD} 8 \mathrm{~T}$ cells, and the in vitro effects often do not corroborate with in vivo effects. Most studies agree that ligation of 4-1BB sends a co-stimulatory signal into the CD4 $\mathrm{T}$ cell and is associated with induction of cytokine production and enhanced $\mathrm{T}$ cell activation and survival, especially in the absence of CD28 signaling. Similar to its effects on the CD4 $\mathrm{T}$ cell, ligation of 4-1BB also sends co-stimulatory signal into the CD8 T cell (46).

Interestingly, administration of an agonistic anti-4-1BB antibody resulted in amelioration of inflammatory arthritis with associated reduction of $\mathrm{B}$ cell responses, and expansion of an IFN- $\gamma$-producing CD8 T cell population in the murine model of CIA $(47,48)$.

In addition to the membrane bound forms, 4-1BB and 4-1BBL can also be present in soluble forms in the serum. Both s4-1BB and s4-1BBL levels are elevated in RA sera and those levels positively correlate with each other and with disease severity. In this same study the expression of membrane 4-1BB was not elevated in RA $(49,50)$. This suggests that the expression and secretion of 4-1BB and its ligand are differentially regulated and adds more complexity to the interpretation of the vivo role of these structures. Currently there is an ongoing phase II study involving anti-4-1BB antibody in patients with melanoma (NCT00612664).

\section{CD4 (OKT4, Leu 3a, T4)}

CD4 is a type I transmembrane glycoprotein and a member of the Ig superfamily. It is a coreceptor in MHC class II antigen-restricted T-cell activation, involved in stabilizing the MHC/TCR complex (51). In addition to MHC class II, ligands for CD4 include viral gp120 protein of HIV retroviruses, IL-16 and gp17. CD4 is also involved in regulation of T-B lymphocyte adhesion in the absence of antigen recognition (52). CD4 is a receptor for IL-16 and binding of IL-16 induces a migratory response in Th1 CD4 T cells. CD4 is expressed on helper $\mathrm{T}$ cells and some myeloid cells.

Monoclonal antibodies to CD4 failed to show efficacy in RA. Administration was associated with infusion reactions, including low-grade fever, flu-like symptoms and unpredictable occurrence of a skin rash and/or vasculitis (53-55). Additionally, infusion resulted in rapid 
decline of CD4 T cells which remained depressed even six months post treatment (56). Further development of these antibodies for treatment of RA was abandoned.

\section{CD5/CD72 (Tp67, T1, Ly1, Leu-1)}

CD5 is a type I transmembrane glycoprotein expressed by most T cells and some B cells. The putative ligand of CD5 in humans is CD72. CD5 can transmit both inhibitory and stimulatory signals depending on the cell type and its maturation stage (51). CD5 transmits inhibitory signals in thymocytes and B1a cells but is a co-stimulatory signal receptor on mature peripheral T cells (51). Expression of CD5 regulates responsiveness of human T cells to IL-1 (52). The B1a CD5-positive population is expanded in RA and Sjogren's syndrome (52).

Anti-CD5 antibody treatment had a partial therapeutic effect in CIA in DBA/1 mice (57). When an anti-CD5 antibody was covalently linked to the A chain of ricin, binding was followed by internalization and intracellular toxin release. Early patient studies of an antiCD5 ricin-linked immunoconjugate demonstrated rapid depletion of CD5 cells but considerable toxicity including fevers, prostration, fluid retention and myalgias $(58,59)$. When tested in placebo-controlled trials at a lower dose in patients with RA, T cell depletion was neither marked nor prolonged and the treatment failed to produce a clinical response (60).

\section{CD40- CD40ligand (Bp50, TNF receptor 5) - ligand CD154 (CD40L}

CD40 is a type I integral membrane glycoprotein that is expressed on APCs and is the receptor for CD40L expressed on activated CD4 T cells, CD8 T cells, mast cells, NK cells, monocytes and activated platelets. Binding of $\mathrm{CD} 40 \mathrm{~L}$ provides a co-stimulatory signal to $\mathrm{B}$ cells, promoting growth, differentiation and isotype switching (51). Binding of CD40L by CD40 transmits activating signals to T cells and APCs to express B7 molecules, which in turn stimulates further T-cell proliferation (61).

IDEC-131 and BG9588 are humanized monoclonal antibodies to CD40L. BG9588 was given to 28 patients with active proliferative lupus nephritis, resulting in a reduction in antidsDNA titers and proteinuria. The trial was stopped early due to the occurrence of thromboembolic events, including two nonfatal myocardial infarctions, which may have been due to the expression of CD40L on platelets $(62,63)$. IDEC-131, when tested in a placebo-controlled trial in patients with mild-to-moderate active systemic lupus erythematosus, demonstrated no thromoboembolic events but no clinical activity (64). Further development of these antibodies was not pursued.

\section{LFA-3 (CD58)/CD2}

LFA-3 is a member of the CD2 family within the Ig superfamily that occurs as a glycophosphatidylinositol-anchored and type I integral membrane protein (51). LFA-3 is the ligand for $\mathrm{CD} 2$ and mediates adhesion between killer and target cells and in cell-mediated cytotoxicity. Adhesion through CD2 occurs between APCs and T lymphocytes, thymocytes and thymic epithelial cells, and $\mathrm{T}$ lymphocytes and erythrocytes.

Alefacept is a dimeric fusion protein consisting of an antigen, 1-92-LFA-3 (CD58) fused with the Fc portion of IgG1. By inhibition of LFA-3/CD2 interactions, alefacept can inhibit immune processes which rely on $\mathrm{T}$ lymphocyte activation in a non-selective manner. Alefacept is approved for the treatment of adult patients with moderate to severe chronic plaque psoriasis who are candidates for systemic therapy or phototherapy. Alefacept should not be administered to patients infected with HIV as it can reduce CD4 T lymphocyte 
counts, potentially accelerating disease progression or increasing complications of disease in these patients

(http://www.fda.gov/Safety/MedWatch/SafetyInformation/

SafetyAlertsforHumanMedicalProducts/ucm150623.htm accessed 9/23/09).

\section{CD11a/CD18}

CD11a is a type I integral membrane glycoprotein and a member of the integrin $\alpha$-chain family. CD11a complexes with CD18 to form leucocyte function associated antigen 1 (LFA-1). Ligands for LFA-1 are CD54 (ICAM-1), CD102 (ICAM-2), CD50 (ICAM-3), ICAM-4, ICAM-5 and JAM-1 (CD321). LFA-1 is an important adhesion and signal transduction molecule involved in inflammation (51).

Efalizumab is a recombinant humanized $\operatorname{IgG}_{1}$ monoclonal antibody that binds to $\mathrm{CD} 11 \mathrm{a}$, the $\alpha$-subunit of LFA-1. LFA-1 binds to ICAM-1, facilitating the migration of T lymphocytes through the endothelial lining during inflammation. Binding of efalizumab to LFA-1 prevents lymphocyte migration through the endothelium, decreasing lymphocyte trafficking to target organs during inflammation. Efalizumab was approved for the treatment of moderate to severe plaque psoriasis in 2003 in the United States and in 2004 in Europe. In February 2009, the FDA issued a Public Health Advisory to notify healthcare professionals of three confirmed, and one possible report of progressive multifocal leukoencephalopathy (PML) caused by reactivation of latent JC virus infection that had occurred in patients receiving efalizumab. Three patients died. Simultaneously, the EMEA recommended suspension of marketing approval of efalizumab. In April 2009, the manufacturer began the voluntarily withdrawal of efalizumab from the worldwide market citing an unfavorable balance between the increased risk of PML and the benefits of treatment of plaque psoriasis (http://www.gene.com/gene/products/information/pdf/raptiva_withdrawal_dhcp.pdf accessed 9/23/2009).

\section{CD49d (Integrin alpha-4-chain, VLA-4-alpha chain}

CD49d is a type I transmembrane glycoprotein which non-covalently associates with CD29 molecules to form VLA-4 (integrin $\alpha 4 / \beta 1$ ) and with the $\beta 7$ integrin subunit to form the $\alpha 4 /$ $\beta 7$ integrin. CD49d regulates multiple inflammatory responses by enhancing adhesion to and rolling of lymphocytes on vascular endothelium by binding to VCAM-1, allowing lymphocyte migration from circulation into tissue (51). CD49d, when associated with $\beta 7$ integrin, is involved in the homing of $\mathrm{T}$ cell subsets to gut mucosal tissue via interaction with MAdCAM-1.

Natalizumab is a humanized $\operatorname{IgG}_{4}$ monoclonal antibody that binds to the $\alpha 4$ subunit of $\alpha 4 \beta 1$ and $\alpha 4 \beta 7$ integrins and prevents binding to their respective endothelial receptors, VCAM-1 and MAdCAM-1. The inhibition of binding to VCAM-1 is believed to prevent the movement of T lymphocytes across the endothelial-cell basal lamina and into the CNS parenchyma, an important step in the initiation of lesions in multiple sclerosis (65). Presumably, inhibition of binding to MAdCAM-1 prevents T cell extravasation to the gut, decreasing inflammation in the inflammatory bowel disease. Natalizumab is approved for the treatment of relapsing multiple sclerosis and Crohn's disease in the United States and relapsing multiple sclerosis in Europe. The biological effect seen with natalizumab in patients with RA receiving methotrexate was not sufficient to warrant further development for RA (NCT00083759).

Natalizumab was approved in November 2004 by the FDA and was withdrawn from the market by its manufacturer in 2005 after it was linked to two cases of PML when administered in combination with interferon beta-1a in the treatment of multiple sclerosis 
and one case of PML in a patient with Crohn's disease (66-68). The drug returned to the market in 2006 under a special risk management plan, called the TYSARBI-TOUCH Prescribing Program. All patients receiving natalizumab therapy in the United States must be enrolled and closely monitored for the occurrence of PML and other serious opportunistic infections. From July 2006 to September 8, 2009, 13 reported cases of natalizumab related PML were confirmed worldwide in patients being treated for multiple sclerosis and the risk for developing PML appears to increase with the number of natalizumab infusions received.

(http://www.fda.gov/Drugs/DrugSafety/

PostmarketDrugSafetyInformationforPatientsandProviders/ucm107198.htm accessed 9/23/2009). Physicians and patients need to be aware of the potential for immunosuppression and risk of PML. All cases of PML and serious infections should be reported to MedWatch, the FDA safety information and adverse event reporting program, to identify risk factors for PML and other serious infection associated with nataluzimab.

\section{CD97/CD55/chondroitin sulfate}

CD97 is a transmembrane protein belonging to the secretin receptor superfamily, G-proteincoupled receptor family and the epidermal growth factor-seven-span transmembrane family (EGF-TM7) of molecules. CD97 is expressed on activated T and B cells and constituitively by monocytes, macrophages, dendritic cells and granulocytes. CD97 binds CD55 and chondroitin sulfate (51). EGF domains mediate CD97 interactions with different ligands, with CD55 interacting with EGF domains 1 and 2, and chondroitin sulfate interacting with EGF domain 4 (51). Increased levels of soluble CD97 have been found in RA synovial fluid by ELISA, and binding of CD97 to CD55 has been observed in RA synovial tissue utilizing binding assays with multivalent fluorescent probes (69-71). A monoclonal, neutralizing antibody to $\mathrm{CD} 97, \mathrm{mAb} 1 \mathrm{~B} 2$, was effective in preventing murine collagen-induced arthritis (72). Inhibition of CD97 has not been attempted in human clinical trials.

\section{CD52}

CD52, a highly N-glycosylated protein, C-terminally anchored in the membrane via glycophosphatidylinositol, is highly expressed on the surface of thymocytes, CD4 and CD8 lymphocytes, B lymphocytes, monocytes, macrophages, NK cells, dendritic cells and eosinophils (51). Alemtuzumab (Campath-1H) is a humanized $\mathrm{IgG}_{1}$ kappa monoclonal antibody to CD52 and is FDA approved for the treatment of B-cell chronic lymphocytic leukemia. In 2005, the FDA issued an alert as three patients in a clinical study of alemtuzumab in multiple sclerosis developed severe idiopathic thrombocytopenic purpura, one of whom died. Alemtuzumab is not approved for use in multiple sclerosis.

Alemtuzumab was tested in RA and caused a dose-dependent cytokine release syndrome and persistent CD4 T cell lymphopenia $(73,74)$. Additionally, impairment of innate immunity resulted from monocyte and NK cell depletion and was associated with two fatal opportunistic infections in patients with RA $(75,76)$. Alemtuzumab is not FDA approved for use in RA.

\section{CD27/CD70 (CD27 ligand)}

CD70 is a type II transmembrane glycoprotein member of the tumor necrosis factor superfamily. CD70 is expressed on activated B cells, T cells, NK cells and dendritic cells. CD70 binds CD27 which is constitutively expressed on resting T cells and is further upregulated upon $\mathrm{T}$ cell activation. CD70-CD27 plays an important role in T cell priming by inducing proliferation of co-stimulated $\mathrm{T}$ cells, enhancing the generation of cytolytic and memory $\mathrm{T}$ cells. 
Increased numbers of circulating CD70 positive CD4 T cells have been observed in RA and systemic lupus erythematosus patients. CD70 over-expression on T cells in SLE patients is due to hypomethylation of DNA sequences that flank the CD70 promoter leading to an inability to down-regulate CD70 expression once it is induced by activation of T cells (7779). An anti-CD70 antibody, used before or after the onset of arthritis in the murine collagen induced arthritis model resulted in improvement in disease severity and reduction of autoantibodies (80). Aberrant CD70 has been detected on a number of hematologic malignancies and some carcinomas, and is being explored as a target for therapeutic antibodies in preclinical trials (81).

\section{Summary}

Inhibition of $\mathrm{T}$ cell co-stimulation is a promising but complex approach to the treatment of immune-mediated diseases. Many of the co-stimulatory molecules discussed are not specific for $\mathrm{T}$ cells and are expressed on other cell lineages. For this reason, interference with these molecules could lead to off-target effects, such as induction of thromboembolic events in patients with SLE by anti-CD40L due to CD40L expression on platelets. Multiple arms of host defense mechanisms are required to combat some infections and weakening them can lead to emergence of opportunistic pathogens, for example the occurrence of JC virus/PML following use of various biologics.. Targeting of diverse molecules and pathways has led to cases of PML in patients receiving rituximab (anti-CD20), natalizumab (anti-CD49d) and efalizumab (anti-CD11a), all presumably through different mechanisms but with the same deleterious outcome. The specific infections that will occur due to inhibition of various costimulatory pathways are not currently accurately predictable, and therefore careful observation of all patients treated with biologics that block co-stimulatory pathways is of paramount importance.

\section{References}

1. Linsley PS, Brady W, Grosmaire L, Aruffo A, Damle NK, Ledbetter JA. Binding of the B cell activation antigen $\mathrm{B} 7$ to $\mathrm{CD} 28$ costimulates T cell proliferation and interleukin 2 mRNA accumulation. J Exp Med. 1991 Mar 1; 173(3):721-30. [PubMed: 1847722]

2. Linsley PS, Greene JL, Brady W, Bajorath J, Ledbetter JA, Peach R. Human B7-1 (CD80) and B7-2 (CD86) bind with similar avidities but distinct kinetics to CD28 and CTLA-4 receptors. Immunity. 1994 Dec; 1(9):793-801. [PubMed: 7534620]

3. Peach RJ, Bajorath J, Brady W, Leytze G, Greene J, Naemura J, et al. Complementarity determining region 1 (CDR1)- and CDR3-analogous regions in CTLA-4 and CD28 determine the binding to B7-1. J Exp Med. 1994 Dec 1; 180(6):2049-58. [PubMed: 7964482]

4. Greene JL, Leytze GM, Emswiler J, Peach R, Bajorath J, Cosand W, et al. Covalent dimerization of CD28/CTLA-4 and oligomerization of CD80/CD86 regulate T cell costimulatory interactions. J Biol Chem. 1996 Oct 25; 271(43):26762-71. [PubMed: 8900156]

5. Orabona C, Grohmann U, Belladonna ML, Fallarino F, Vacca C, Bianchi R, et al. CD28 induces immunostimulatory signals in dendritic cells via CD80 and CD86. Nat Immunol. 2004 Nov; 5(11): 1134-42. [PubMed: 15467723]

6. Walunas TL, Lenschow DJ, Bakker CY, Linsley PS, Freeman GJ, Green JM, et al. CTLA-4 can function as a negative regulator of T cell activation. Immunity. 1994 Aug; 1(5):405-13. [PubMed: $7882171]$

7. Krummel MF, Allison JP. CD28 and CTLA-4 have opposing effects on the response of T cells to stimulation. J Exp Med. 1995 Aug 1; 182(2):459-65. [PubMed: 7543139]

8. London CA, Lodge MP, Abbas AK. Functional responses and costimulator dependence of memory CD4+ T cells. J Immunol. 2000 Jan 1; 164(1):265-72. [PubMed: 10605020]

9. Ndejembi MP, Teijaro JR, Patke DS, Bingaman AW, Chandok MR, Azimzadeh A, et al. Control of memory CD4 T cell recall by the CD28/B7 costimulatory pathway. J Immunol. 2006 Dec 1; 177(11):7698-706. [PubMed: 17114440] 
10. Suntharalingam G, Perry MR, Ward S, Brett SJ, Castello-Cortes A, Brunner MD, et al. Cytokine storm in a phase 1 trial of the anti-CD28 monoclonal antibody TGN1412. N Engl J Med. 2006 Sep 7; 355(10):1018-28. [PubMed: 16908486]

11. Webb LM, Walmsley MJ, Feldmann M. Prevention and amelioration of collagen-induced arthritis by blockade of the CD28 co-stimulatory pathway: requirement for both B7-1 and B7-2. Eur J Immunol. 1996 Oct; 26(10):2320-8. [PubMed: 8898940]

12. Moreland LW, Alten R, Van den Bosch F, Appelboom T, Leon M, Emery P, et al. Costimulatory blockade in patients with rheumatoid arthritis: a pilot, dose-finding, double-blind, placebocontrolled clinical trial evaluating CTLA-4Ig and LEA29Y eighty-five days after the first infusion. Arthritis Rheum. 2002 Jun; 46(6):1470-9. [PubMed: 12115176]

13. Kremer JM, Westhovens R, Leon M, Di Giorgio E, Alten R, Steinfeld S, et al. Treatment of rheumatoid arthritis by selective inhibition of T-cell activation with fusion protein CTLA4Ig. N Engl J Med. 2003 Nov 13; 349(20):1907-15. [PubMed: 14614165]

14. Kremer JM, Dougados M, Emery P, Durez P, Sibilia J, Shergy W, et al. Treatment of rheumatoid arthritis with the selective costimulation modulator abatacept: twelvemonth results of a phase iib, double-blind, randomized, placebo-controlled trial. Arthritis Rheum. 2005 Aug; 52(8):2263-71. [PubMed: 16052582]

15. Westhovens R, Kremer JM, Moreland LW, Emery P, Russell AS, Li T, et al. Safety and efficacy of the selective costimulation modulator abatacept in patients with rheumatoid arthritis receiving background methotrexate: a 5-year extended phase IIB study. J Rheumatol. 2009 Apr; 36(4):73642. [PubMed: 19273451]

16. Genovese MC, Becker JC, Schiff M, Luggen M, Sherrer Y, Kremer J, et al. Abatacept for rheumatoid arthritis refractory to tumor necrosis factor alpha inhibition. N Engl J Med. 2005 Sep 15; 353(11):1114-23. [PubMed: 16162882]

17. Genovese MC, Schiff M, Luggen M, Becker JC, Aranda R, Teng J, et al. Efficacy and safety of the selective co-stimulation modulator abatacept following 2 years of treatment in patients with rheumatoid arthritis and an inadequate response to anti-tumour necrosis factor therapy. Ann Rheum Dis. 2008 Apr; 67(4):547-54. [PubMed: 17921185]

18. Schiff M, Keiserman M, Codding C, Songcharoen S, Berman A, Nayiager S, et al. Efficacy and safety of abatacept or infliximab vs placebo in ATTEST: a phase III, multi-centre, randomised, double-blind, placebo-controlled study in patients with rheumatoid arthritis and an inadequate response to methotrexate. Ann Rheum Dis. 2008 Aug; 67(8):1096-103. [PubMed: 18055472]

19. Kremer JM, Genant HK, Moreland LW, Russell AS, Emery P, Abud-Mendoza C, et al. Effects of abatacept in patients with methotrexate-resistant active rheumatoid arthritis: a randomized trial. Ann Intern Med. 2006 Jun 20; 144(12):865-76. [PubMed: 16785475]

20. Genant HK, Peterfy CG, Westhovens R, Becker JC, Aranda R, Vratsanos G, et al. Abatacept inhibits progression of structural damage in rheumatoid arthritis: results from the long-term extension of the AIM trial. Ann Rheum Dis. 2008 Aug; 67(8):1084-9. [PubMed: 18086727]

21. Kremer JM, Genant HK, Moreland LW, Russell AS, Emery P, Abud-Mendoza C, et al. Results of a two-year followup study of patients with rheumatoid arthritis who received a combination of abatacept and methotrexate. Arthritis Rheum. 2008 Apr; 58(4):953-63. [PubMed: 18383390]

22. Westhovens R, Robles M, Ximenes AC, Nayiager S, Wollenhaupt J, Durez P, et al. Clinical efficacy and safety of abatacept in methotrexate-naive patients with early rheumatoid arthritis and poor prognostic factors. Ann Rheum Dis. 2009 Jan 5.

23. Weinblatt M, Combe B, Covucci A, Aranda R, Becker JC, Keystone E. Safety of the selective costimulation modulator abatacept in rheumatoid arthritis patients receiving background biologic and nonbiologic disease-modifying antirheumatic drugs: A one-year randomized, placebocontrolled study. Arthritis Rheum. 2006 Sep; 54(9):2807-16. [PubMed: 16947384]

24. Weinblatt M, Schiff M, Goldman A, Kremer J, Luggen M, Li T, et al. Selective costimulation modulation using abatacept in patients with active rheumatoid arthritis while receiving etanercept: a randomised clinical trial. Ann Rheum Dis. 2007 Feb; 66(2):228-34. [PubMed: 16935912]

25. Weisman MH, Durez P, Hallegua D, Aranda R, Becker JC, Nuamah I, et al. Reduction of inflammatory biomarker response by abatacept in treatment of rheumatoid arthritis. J Rheumatol. 2006 Nov; 33(11):2162-6. [PubMed: 17014006] 
26. Buch MH, Boyle DL, Rosengren S, Saleem B, Reece RJ, Rhodes LA, et al. Mode of action of abatacept in rheumatoid arthritis patients having failed tumour necrosis factor blockade: a histological, gene expression and dynamic magnetic resonance imaging pilot study. Ann Rheum Dis. 2009 Jul; 68(7):1220-7. [PubMed: 18772191]

27. Larsen CP, Pearson TC, Adams AB, Tso P, Shirasugi N, Strobertm E, et al. Rational development of LEA29Y (belatacept), a high-affinity variant of CTLA4-Ig with potent immunosuppressive properties. Am J Transplant. 2005 Mar; 5(3):443-53. [PubMed: 15707398]

28. Latek R, Fleener C, Lamian V, Kulbokas E 3rd, Davis PM, Suchard SJ, et al. Assessment of belatacept-mediated costimulation blockade through evaluation of CD80/86-receptor saturation. Transplantation. 2009 Mar 27; 87(6):926-33. [PubMed: 19300198]

29. Vincenti F, Larsen C, Durrbach A, Wekerle T, Nashan B, Blancho G, et al. Costimulation blockade with belatacept in renal transplantation. N Engl J Med. 2005 Aug 25; 353(8):770-81. [PubMed: 16120857]

30. Walker LS, Gulbranson-Judge A, Flynn S, Brocker T, Raykundalia C, Goodall M, et al. Compromised OX40 function in CD28-deficient mice is linked with failure to develop CXC chemokine receptor 5-positive CD4 cells and germinal centers. J Exp Med. 1999 Oct 18; 190(8): 1115-22. [PubMed: 10523609]

31. Ohshima Y, Tanaka Y, Tozawa H, Takahashi Y, Maliszewski C, Delespesse G. Expression and function of OX40 ligand on human dendritic cells. J Immunol. 1997 Oct 15; 159(8):3838-48. [PubMed: 9378971]

32. Murata K, Ishii N, Takano H, Miura S, Ndhlovu LC, Nose M, et al. Impairment of antigenpresenting cell function in mice lacking expression of OX40 ligand. J Exp Med. 2000 Jan 17; 191(2):365-74. [PubMed: 10637280]

33. Saijo S, Asano M, Horai R, Yamamoto H, Iwakura Y. Suppression of autoimmune arthritis in interleukin-1-deficient mice in which $\mathrm{T}$ cell activation is impaired due to low levels of CD40 ligand and OX40 expression on T cells. Arthritis Rheum. 2002 Feb; 46(2):533-44. [PubMed: 11840457]

34. Yoshioka T, Nakajima A, Akiba H, Ishiwata T, Asano G, Yoshino S, et al. Contribution of OX40/ OX40 ligand interaction to the pathogenesis of rheumatoid arthritis. Eur J Immunol. 2000 Oct; 30(10):2815-23. [PubMed: 11069062]

35. Boot EP, Koning GA, Storm G, Wagenaar-Hilbers JP, van Eden W, Everse LA, et al. CD134 as target for specific drug delivery to auto-aggressive CD4+ T cells in adjuvant arthritis. Arthritis Res Ther. 2005; 7(3):R604-15. [PubMed: 15899047]

36. Brugnoni D, Bettinardi A, Malacarne F, Airo P, Cattaneo R. CD134/OX40 expression by synovial fluid CD4+ T lymphocytes in chronic synovitis. Br J Rheumatol. 1998 May; 37(5):584-5. [PubMed: 9651095]

37. Giacomelli R, Passacantando A, Perricone R, Parzanese I, Rascente M, Minisola G, et al. T lymphocytes in the synovial fluid of patients with active rheumatoid arthritis display CD134OX40 surface antigen. Clin Exp Rheumatol. 2001 May-Jun; 19(3):317-20. [PubMed: 11407087]

38. Passacantando A, Parzanese I, Rascente M, Petrucci C, Minisola G, Tonietti G. Synovial fluid OX40T lymphocytes of patients with rheumatoid arthritis display a Th2/Th0 polarization. Int J Immunopathol Pharmacol. 2006 Jul-Sep; 19(3):499-505. [PubMed: 17026834]

39. Imura A, Hori T, Imada K, Ishikawa T, Tanaka Y, Maeda M, et al. The human OX40/gp34 system directly mediates adhesion of activated T cells to vascular endothelial cells. J Exp Med. 1996 May 1; 183(5):2185-95. [PubMed: 8642328]

40. Stuber E, Neurath M, Calderhead D, Fell HP, Strober W. Cross-linking of OX40 ligand, a member of the TNF/NGF cytokine family, induces proliferation and differentiation in murine splenic B cells. Immunity. 1995 May; 2(5):507-21. [PubMed: 7749983]

41. Stuber E, Strober W. The T cell-B cell interaction via OX40-OX40L is necessary for the T celldependent humoral immune response. J Exp Med. 1996 Mar 1; 183(3):979-89. [PubMed: 8642301]

42. Nurieva RI, Treuting P, Duong J, Flavell RA, Dong C. Inducible costimulator is essential for collagen-induced arthritis. J Clin Invest. 2003 Mar; 111(5):701-6. [PubMed: 12618524] 
43. Iwai H, Kozono Y, Hirose S, Akiba H, Yagita H, Okumura K, et al. Amelioration of collageninduced arthritis by blockade of inducible costimulator-B7 homologous protein costimulation. $\mathrm{J}$ Immunol. 2002 Oct 15; 169(8):4332-9. [PubMed: 12370365]

44. Okamoto T, Saito S, Yamanaka H, Tomatsu T, Kamatani N, Ogiuchi H, et al. Expression and function of the co-stimulator H4/ICOS on activated T cells of patients with rheumatoid arthritis. $J$ Rheumatol. 2003 Jun; 30(6):1157-63. [PubMed: 12784384]

45. Ruth JH, Rottman JB, Kingsbury GA, Coyle AJ, Haines GK 3rd, Pope RM, et al. ICOS and B7 costimulatory molecule expression identifies activated cellular subsets in rheumatoid arthritis. Cytometry A. 2007 May; 71(5):317-26. [PubMed: 17323353]

46. Wang C, Lin GH, McPherson AJ, Watts TH. Immune regulation by 4-1BB and 4-1BBL: complexities and challenges. Immunol Rev. 2009 May; 229(1):192-215. [PubMed: 19426223]

47. Foell JL, Diez-Mendiondo BI, Diez OH, Holzer U, Ruck P, Bapat AS, et al. Engagement of the CD137 (4-1BB) costimulatory molecule inhibits and reverses the autoimmune process in collageninduced arthritis and establishes lasting disease resistance. Immunology. 2004 Sep; 113(1):89-98. [PubMed: 15312139]

48. Seo SK, Choi JH, Kim YH, Kang WJ, Park HY, Suh JH, et al. 4-1BB-mediated immunotherapy of rheumatoid arthritis. Nat Med. 2004 Oct; 10(10):1088-94. [PubMed: 15448685]

49. Jung HW, Choi SW, Choi JI, Kwon BS. Serum concentrations of soluble 4-1BB and 4-1BB ligand correlated with the disease severity in rheumatoid arthritis. Exp Mol Med. 2004 Feb 29; 36(1):1322. [PubMed: 15031666]

50. Michel J, Langstein J, Hofstadter F, Schwarz H. A soluble form of CD137 (ILA/4-1BB), a member of the TNF receptor family, is released by activated lymphocytes and is detectable in sera of patients with rheumatoid arthritis. Eur J Immunol. 1998 Jan; 28(1):290-5. [PubMed: 9485208]

51. Zola, H. Leukocyte and stromal cell molecules: the CD markers. Hoboken, N.J: Wiley-Liss; 2007.

52. Mason, D. Leucocyte typing VII: white cell differentiation antigens: proceedings of the Seventh International Workshop and Conference held in Harrogate, United Kindom. Oxford: Oxford University Press; 2002.

53. Isaacs JD, Burrows N, Wing M, Keogan MT, Rebello PR, Watts RA, et al. Humanized anti-CD4 monoclonal antibody therapy of autoimmune and inflammatory disease. Clin Exp Immunol. 1997 Nov; 110(2):158-66. [PubMed: 9367397]

54. Choy EH, Connolly DJ, Rapson N, Jeal S, Brown JC, Kingsley GH, et al. Pharmacokinetic, pharmacodynamic and clinical effects of a humanized IgG1 anti-CD4 monoclonal antibody in the peripheral blood and synovial fluid of rheumatoid arthritis patients. Rheumatology (Oxford). 2000 Oct; 39(10):1139-46. [PubMed: 11035136]

55. Choy EH, Panayi GS, Emery P, Madden S, Breedveld FC, Kraan MC, et al. Repeat-cycle study of high-dose intravenous 4162W94 anti-CD4 humanized monoclonal antibody in rheumatoid arthritis. A randomized placebo-controlled trial. Rheumatology (Oxford). 2002 Oct; 41(10):11428. [PubMed: 12364634]

56. Moreland LW, Bucy RP, Tilden A, Pratt PW, LoBuglio AF, Khazaeli M, et al. Use of a chimeric monoclonal anti-CD4 antibody in patients with refractory rheumatoid arthritis. Arthritis Rheum. 1993 Mar; 36(3):307-18. [PubMed: 8095785]

57. Plater-Zyberk C, Taylor PC, Blaylock MG, Maini RN. Anti-CD5 therapy decreases severity of established disease in collagen type II-induced arthritis in DBA/1 mice. Clin Exp Immunol. 1994 Dec; 98(3):442-7. [PubMed: 7527741]

58. Strand V, Lipsky PE, Cannon GW, Calabrese LH, Wiesenhutter C, Cohen SB, et al. Effects of administration of an anti-CD5 plus immunoconjugate in rheumatoid arthritis. Results of two phase II studies. The CD5 Plus Rheumatoid Arthritis Investigators Group. Arthritis Rheum. 1993 May; 36(5):620-30. [PubMed: 7683881]

59. Fox DA. Biological therapies: a novel approach to the treatment of autoimmune disease. Am J Med. 1995 Jul; 99(1):82-8. [PubMed: 7598148]

60. Olsen NJ, Brooks RH, Cush JJ, Lipsky PE, St Clair EW, Matteson EL, et al. A double-blind, placebo-controlled study of anti-CD5 immunoconjugate in patients with rheumatoid arthritis. The Xoma RA Investigator Group. Arthritis Rheum. 1996 Jul; 39(7):1102-8. [PubMed: 8670317] 
61. Janeway, CA. Immunobiology: the immune systemt in health and disease. 5. New York: Garland; 2001.

62. Boumpas DT, Furie R, Manzi S, Illei GG, Wallace DJ, Balow JE, et al. A short course of BG9588 (anti-CD40 ligand antibody) improves serologic activity and decreases hematuria in patients with proliferative lupus glomerulonephritis. Arthritis Rheum. 2003 Mar; 48(3):719-27. [PubMed: 12632425]

63. Bhat P, Radhakrishnan J. B lymphocytes and lupus nephritis: new insights into pathogenesis and targeted therapies. Kidney Int. 2008 Feb; 73(3):261-8. [PubMed: 18004299]

64. Kalunian KC, Davis JC Jr, Merrill JT, Totoritis MC, Wofsy D. Treatment of systemic lupus erythematosus by inhibition of $\mathrm{T}$ cell costimulation with anti-CD154: a randomized, double-blind, placebo-controlled trial. Arthritis Rheum. 2002 Dec; 46(12):3251-8. [PubMed: 12483729]

65. Polman CH, O’Connor PW, Havrdova E, Hutchinson M, Kappos L, Miller DH, et al. A randomized, placebo-controlled trial of natalizumab for relapsing multiple sclerosis. N Engl J Med. 2006 Mar 2; 354(9):899-910. [PubMed: 16510744]

66. Kleinschmidt-DeMasters BK, Tyler KL. Progressive multifocal leukoencephalopathy complicating treatment with natalizumab and interferon beta-1a for multiple sclerosis. N Engl J Med. $2005 \mathrm{Jul}$ 28; 353(4):369-74. [PubMed: 15947079]

67. Langer-Gould A, Atlas SW, Green AJ, Bollen AW, Pelletier D. Progressive multifocal leukoencephalopathy in a patient treated with natalizumab. N Engl J Med. 2005 Jul 28; 353(4): 375-81. [PubMed: 15947078]

68. Van Assche G, Van Ranst M, Sciot R, Dubois B, Vermeire S, Noman M, et al. Progressive multifocal leukoencephalopathy after natalizumab therapy for Crohn's disease. N Engl J Med. 2005 Jul 28; 353(4):362-8. [PubMed: 15947080]

69. Gray JX, Haino M, Roth MJ, Maguire JE, Jensen PN, Yarme A, et al. CD97 is a processed, seventransmembrane, heterodimeric receptor associated with inflammation. J Immunol. 1996 Dec 15; 157(12):5438-47. [PubMed: 8955192]

70. Hamann J, Wishaupt JO, van Lier RA, Smeets TJ, Breedveld FC, Tak PP. Expression of the activation antigen CD97 and its ligand CD55 in rheumatoid synovial tissue. Arthritis Rheum. 1999 Apr; 42(4):650-8. [PubMed: 10211878]

71. Kop EN, Kwakkenbos MJ, Teske GJ, Kraan MC, Smeets TJ, Stacey M, et al. Identification of the epidermal growth factor-TM7 receptor EMR2 and its ligand dermatan sulfate in rheumatoid synovial tissue. Arthritis Rheum. 2005 Feb; 52(2):442-50. [PubMed: 15693006]

72. Kop EN, Adriaansen J, Smeets TJ, Vervoordeldonk MJ, van Lier RA, Hamann J, et al. CD97 neutralisation increases resistance to collagen-induced arthritis in mice. Arthritis Res Ther. 2006; 8(5):R155. [PubMed: 17007638]

73. Strand V, Kimberly R, Isaacs JD. Biologic therapies in rheumatology: lessons learned, future directions. Nat Rev Drug Discov. 2007 Jan; 6(1):75-92. [PubMed: 17195034]

74. Brett S, Baxter G, Cooper H, Johnston JM, Tite J, Rapson N. Repopulation of blood lymphocyte sub-populations in rheumatoid arthritis patients treated with the depleting humanized monoclonal antibody, CAMPATH-1H. Immunology. 1996 May; 88(1):13-9. [PubMed: 8707338]

75. Isaacs JD, Manna VK, Rapson N, Bulpitt KJ, Hazleman BL, Matteson EL, et al. CAMPATH-1H in rheumatoid arthritis--an intravenous dose-ranging study. Br J Rheumatol. 1996 Mar; 35(3):23140. [PubMed: 8620297]

76. Weinblatt ME, Maddison PJ, Bulpitt KJ, Hazleman BL, Urowitz MB, Sturrock RD, et al. CAMPATH-1H, a humanized monoclonal antibody, in refractory rheumatoid arthritis. An intravenous dose-escalation study. Arthritis Rheum. 1995 Nov; 38(11):1589-94. [PubMed: 7488279]

77. Oelke K, Lu Q, Richardson D, Wu A, Deng C, Hanash S, et al. Overexpression of CD70 and overstimulation of IgG synthesis by lupus T cells and T cells treated with DNA methylation inhibitors. Arthritis Rheum. 2004 Jun; 50(6):1850-60. [PubMed: 15188362]

78. Lu Q, Wu A, Richardson BC. Demethylation of the same promoter sequence increases CD70 expression in lupus T cells and T cells treated with lupus-inducing drugs. J Immunol. 2005 May 15; 174(10):6212-9. [PubMed: 15879118] 
79. Lee WW, Yang ZZ, Li G, Weyand CM, Goronzy JJ. Unchecked CD70 expression on T cells lowers threshold for T cell activation in rheumatoid arthritis. J Immunol. 2007 Aug 15; 179(4): 2609-15. [PubMed: 17675524]

80. Oflazoglu E, Boursalian TE, Zeng W, Edwards AC, Duniho S, McEarchern JA, et al. Blocking of CD27-CD70 pathway by anti-CD70 antibody ameliorates joint disease in murine collageninduced arthritis. J Immunol. 2009 Sep 15; 183(6):3770-7. [PubMed: 19710474]

81. McEarchern JA, Smith LM, McDonagh CF, Klussman K, Gordon KA, Morris-Tilden CA, et al. Preclinical characterization of SGN-70, a humanized antibody directed against CD70. Clin Cancer Res. 2008 Dec 1; 14(23):7763-72. [PubMed: 19047103] 


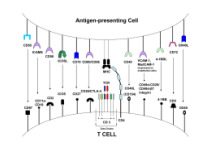

Figure 1.

Co-stimulatory receptor-ligand pairs present on $\mathrm{T}$ cells and antigen presenting cells. On the T cell CD4, CD2, CD5, CD28, CD11a-CD18, CD49d-CD29/CD49d- $\beta 7$ and CD27 are constitutively expressed. CTLA-4, OX40, ICOS, 4-1BB, CD40L (CD154) and CD97 are upregulated on the $\mathrm{T}$ cell surface following activation via the $\mathrm{T}$ cell receptor. 
Table 1

Cellular distribution of costimulatory molecules on $\mathrm{T}$ cells and their corresponding receptor or ligand on accessory cells.

\begin{tabular}{|c|c|c|c|c|}
\hline $\begin{array}{l}\text { Costimulatory } \\
\text { molecule on } \mathbf{T} \\
\text { cells. }\end{array}$ & $\begin{array}{l}\text { Expression profile of } \\
\text { molecule on } T \text { cell surface }\end{array}$ & Corresponding ligand/receptor & $\begin{array}{l}\text { Cells which express } \\
\text { the corresponding } \\
\text { ligand/receptor }\end{array}$ & $\begin{array}{l}\text { Expression profile of } \\
\text { corresponding receptor/ } \\
\text { ligand }\end{array}$ \\
\hline $\begin{array}{l}\text { CD28/CTLA-4 } \\
\text { (resting and } \\
\text { activated, and } \\
\text { memory T } \\
\text { cells) }\end{array}$ & $\begin{array}{l}\text { Constitutive/CTLA- } 4 \text { only } \\
\text { induced after activation }\end{array}$ & CD80/86 & $\begin{array}{l}\text { Antigen presenting } \\
\text { cells, and on occasional } \\
\text { activated T cells }\end{array}$ & $\begin{array}{l}\text { Constitutive, further } \\
\text { upregulated after activation/ } \\
\text { maturation. }\end{array}$ \\
\hline $\begin{array}{l}\text { OX } 40 \\
\text { (activated T } \\
\text { cells, memory } \\
\text { T cells) }\end{array}$ & $\begin{array}{l}\text { Expressed following } \\
\text { activation via TCR and } \\
\text { CD28 }\end{array}$ & OX40L & $\begin{array}{l}\text { Dendritic cells, } \\
\text { macrophages, and B } \\
\text { cells }\end{array}$ & $\begin{array}{l}\text { Expressed following } \\
\text { activation and maturation. }\end{array}$ \\
\hline $\begin{array}{l}\text { ICOS } \\
\text { (activated T } \\
\text { cells, and CD4 } \\
\text { memory T } \\
\text { cells in RA) }\end{array}$ & $\begin{array}{l}\text { Induced following } \\
\text { activation via TCR and } \\
\text { CD28 }\end{array}$ & ICOSL & B cells and monocytes & $\begin{array}{l}\text { Constitutive and further } \\
\text { augmented following } \\
\text { activation and maturation. }\end{array}$ \\
\hline $\begin{array}{l}\text { 4-1BB } \\
\text { (activated CD4 } \\
\text { and CD8 T } \\
\text { cells) }\end{array}$ & $\begin{array}{l}\text { Induced following } \\
\text { activation via TCR and } \\
\text { CD28 }\end{array}$ & 4-1BBL & $\begin{array}{l}\text { B cells, dendritic cells, } \\
\text { and macrophages }\end{array}$ & $\begin{array}{l}\text { Expressed following } \\
\text { activation and maturation. }\end{array}$ \\
\hline $\begin{array}{l}\text { CD4 (T helper } \\
\text { cells) }\end{array}$ & Constitutive & MHC II & Antigen presenting cells & $\begin{array}{l}\text { Constitutive, further } \\
\text { upregulated after activation }\end{array}$ \\
\hline $\begin{array}{l}\text { CD5 } \\
\text { (thymocytes, T } \\
\text { cells) }\end{array}$ & Constitutive & CD72 & Antigen presenting cells & Constitutive \\
\hline $\begin{array}{l}\text { CD154 } \\
\text { (CD40L) } \\
\text { (activated T } \\
\text { cells) }\end{array}$ & Upregulated after activation & CD40 & $\begin{array}{l}\text { B cells, monocytes, } \\
\text { dendritic cells, } \\
\text { epithelial cells, } \\
\text { endothelial cells, } \\
\text { fibroblasts, } \\
\text { keratinocytes }\end{array}$ & $\begin{array}{l}\text { Constitutive and } \\
\text { upregulated following } \\
\text { activation. }\end{array}$ \\
\hline $\begin{array}{l}\text { CD2 } \\
\text { (thymocytes, } \mathrm{T} \\
\text { cells) }\end{array}$ & Constitutive & CD58 & $\begin{array}{l}\text { Leukocytes, } \\
\text { erythrocytes, } \\
\text { endothelial and } \\
\text { epithelial cells, } \\
\text { fibroblasts and smooth } \\
\text { muscle }\end{array}$ & $\begin{array}{l}\text { Constitutive, further } \\
\text { upregulated by activation }\end{array}$ \\
\hline $\begin{array}{l}\text { CD11a-CD18 } \\
\text { (LFA-1) } \\
\text { (memory T } \\
\text { cells) }\end{array}$ & Constitutive & $\begin{array}{l}\text { CD54 (ICAM-1), CD102 } \\
\text { (ICAM-2), CD50 (ICAM-3), } \\
\text { CD242 (ICAM-4), ICAM-5, } \\
\text { CD321 (JAM-1) }\end{array}$ & $\begin{array}{l}\text { Activated T cells, } \\
\text { activated B cells, } \\
\text { monocytes, epithelial } \\
\text { cells, endothelial cells } \\
\text { and fibroblasts }\end{array}$ & $\begin{array}{l}\text { Constitutive and further } \\
\text { upregulated after activation }\end{array}$ \\
\hline $\begin{array}{l}\text { CD49d-CD29/ } \\
\text { CD49d- } \beta 7 \\
\text { integrin } \\
\text { (activated T } \\
\text { cells) }\end{array}$ & $\begin{array}{l}\text { Constitutive, upregulated } \\
\text { after activation }\end{array}$ & VCAM-1/VCAM-1, MadCAM-1 & Endothelial cells, & Upregulated upon activation \\
\hline CD97 (T cells) & Upregulated by activation & CD55 & $\begin{array}{l}\text { Wide expression } \\
\text { including erythrocytes }\end{array}$ & Constitutive \\
\hline $\begin{array}{l}\text { CD27 } \\
\text { (thymocytes, T } \\
\text { cells) }\end{array}$ & $\begin{array}{l}\text { Constitutive, upregulated } \\
\text { after activation. }\end{array}$ & CD70 & $\begin{array}{l}\text { T cells, B cells, NK } \\
\text { cells }\end{array}$ & Upregulated after activation \\
\hline
\end{tabular}


Table 2

The outcome of targeting co-stimulatory receptor-ligand pairs in preclinical animal models as well as in human diseases.

\begin{tabular}{|c|c|c|}
\hline Receptor/ligand targeted & Human/animal studies reported & Outcome \\
\hline \multirow[t]{3}{*}{ CD28:CTLA-4/CD80:CD86 } & $\begin{array}{l}\text { - } \\
\text { - }\end{array}$ & $\begin{array}{l}\text { Infusion was associated with } \\
\text { acute onset, severe cytokine storm } \\
\text { and multiorgan failure. Trial } \\
\text { suspended and drug withdrawn. }\end{array}$ \\
\hline & $\begin{array}{l}\text { - CTLA-4Ig (Abatacept) Preclinical studies in } \\
\text { animals and several clinical trials in patients } \\
\text { with RA }\end{array}$ & $\begin{array}{l}\text { - Significant therapeutic response } \\
\text { and acceptable risk profile. } \\
\text { - FDA approved for treatment of } \\
\text { RA. }\end{array}$ \\
\hline & $\begin{array}{ll}\text { - } & \text { Modified CTLA-4Ig (Belatacept) } \\
\text { - } & \text { Phase II trial in patients with RA. }\end{array}$ & - $\quad$ Trial completed. Results pending. \\
\hline OX40/OX40L & $\begin{array}{l}\text { - OX40 expression is enhanced during arthritis } \\
\text { in animal models. } \\
\text { OX40 and OX40L expression on synovial T } \\
\text { cells is increased in RA. } \\
\text { - Anti OX40 and anti-OX40L antibody has } \\
\text { been tested in the animal model of RA. }\end{array}$ & $\begin{array}{l}\text { Anti-OX40L antibody and } \\
\text { liposome coated with anti-OX40 } \\
\text { antibody has been shown to } \\
\text { reduce severity of arthritis in } \\
\text { animal models of RA. }\end{array}$ \\
\hline ICOS/ICOSL & $\begin{array}{l}\text { - } \quad \text { ICOS deficient mice have reduced arthritis. } \\
\text { Expression of ICOS/ICOSL is increased in the } \\
\text { RA synovium and synovial fluid. } \\
\text { - Anti ICOSL antibody has been tested in an } \\
\text { animal model of RA. } \\
\text { - A phase I trial with anti ICOSL antibody is } \\
\text { underway in patients with RA. }\end{array}$ & $\begin{array}{l}\text { Anti-ICOSL antibody resulted in } \\
\text { reduced severity of arthritis in } \\
\text { animal models. }\end{array}$ \\
\hline $4-1 \mathrm{BB} / 4-1 \mathrm{BBL}$ & $\begin{array}{l}\text { Increased expression of 4-1BB in the RA } \\
\text { synovium. } \\
\text { - Increased levels of s4-1BB and s4-1BB L in } \\
\text { RA synovium and synovial fluid. } \\
\text { - An agonistic anti-4-1BB antibody was tested } \\
\text { in an animal model of RA. }\end{array}$ & $\begin{array}{l}\text { Administration of agonistic anti } \\
\text { 4-1BB antibody was associated } \\
\text { with reduced severity of arthritis } \\
\text { in animal models of RA. }\end{array}$ \\
\hline CD4/MHC Class II & $\begin{array}{l}\text { - Phase I and II clinical trials in patients with } \\
\text { RA. }\end{array}$ & $\begin{array}{ll} & \text { Failed to show therapeutic } \\
\text { response in patients with RA. }\end{array}$ \\
\hline $\mathrm{CD} 5 / \mathrm{CD} 72$ & - $\quad$ Tested in animal model & $\begin{array}{l}\text { - A partial therapeutic effect in was } \\
\text { seen in the mouse model of RA. }\end{array}$ \\
\hline $\mathrm{CD} 40 / \mathrm{CD} 40 \mathrm{~L}$ & $\begin{array}{l}\text { Anti CD40L antibody -- BG9588 and IDEC } \\
131 \text { Clinical trials have been done in patients } \\
\text { with systemic lupus erythematosus. }\end{array}$ & $\begin{array}{l}\text { - Failed to show response in } \\
\text { patients with systemic lupus } \\
\text { erythematosus. }\end{array}$ \\
\hline $\mathrm{CD} 2 / \mathrm{CD} 58$ & $\begin{array}{l}\text { - Alefacept is a fusion protein with 1-92-LFA-3 } \\
\text { (CD58) fused with an immunoglobulin IgG1 } \\
\text { dimer. } \\
\text { Clinical trials have been done in patients with } \\
\text { psoriasis. }\end{array}$ & $\begin{array}{l}\text { Significant therapeutic } \\
\text { improvement. Alefacept is FDA } \\
\text { approved for treatment of } \\
\text { moderate to severe chronic plaque } \\
\text { psoriasis. }\end{array}$ \\
\hline
\end{tabular}




\begin{tabular}{|c|c|c|}
\hline Receptor/ligand targeted & Human/animal studies reported & Outcome \\
\hline $\begin{array}{l}\text { CD11a-CD18/CD54 } \\
\text { (ICAM-1), CD102 (ICAM-2), } \\
\text { CD50 (ICAM-3), CD242 } \\
\text { (ICAM-4), ICAM-5, CD321 } \\
\text { (JAM-1) }\end{array}$ & $\begin{array}{l}\text { Efalizumab is a recombinant humanized } \operatorname{IgG}_{1} \\
\text { monoclonal antibody that binds to CD11a. } \\
\text { Clinical trials have been done in patients with } \\
\text { psoriasis. }\end{array}$ & $\begin{array}{l}\text { Efalizumab was approved for } \\
\text { moderate to severe plaque } \\
\text { psoriasis in } 2003 \text {. } \\
\text { Withdrawn from the market in } \\
\text { 2009. }\end{array}$ \\
\hline $\begin{array}{l}\text { CD } 49 d-C D 29, \text { CD } 49 d-\beta 7 \\
\text { integrin/VCAM-1, } \\
\text { MAdCAM-1 }\end{array}$ & $\begin{array}{l}\text { - Natalizumab is a humanized } \mathrm{IgG}_{4} \text { monoclonal } \\
\text { antibody that binds to the } \alpha 4 \text { subunit of } \alpha 4 \beta 1 \\
\text { and } \alpha 4 \beta 7 \text { integrins. } \\
\text { - Clinical trials have been done in patients with } \\
\text { multiple sclerosis, Crohn's disease, and RA. }\end{array}$ & $\begin{array}{l}\text { - Natalizumab is FDA approved for } \\
\text { the treatment of relapsing multiple } \\
\text { sclerosis and Crohn's disease. } \\
\text { - Failed to show response in } \\
\text { patients with RA. }\end{array}$ \\
\hline $\begin{array}{l}\text { CD97/CD55 and chondroitin } \\
\text { sulfate }\end{array}$ & $\begin{array}{l}\text { - Soluble CD97 found in synovial fluid of } \\
\text { rheumatoid arthritis patients and binding of } \\
\text { CD97 to CD55 has been observed in synovial } \\
\text { tissue of patients with RA. } \\
\text { - Tested in animal model of RA }\end{array}$ & $\begin{array}{l}\text { A monoclonal, neutralizing } \\
\text { antibody to CD97, mAb 1B2, was } \\
\text { effective in preventing joint } \\
\text { inflammation in an animal model } \\
\text { of RA. }\end{array}$ \\
\hline CD52 (Campath-1H) & $\begin{array}{l}\text { Alemtuzumab is a humanized } \operatorname{IgG}_{1} \text { kappa } \\
\text { monoclonal antibody to CD52. Clinical trials } \\
\text { have been done in patients with hematologic } \\
\text { malignancies and RA. }\end{array}$ & $\begin{array}{l}\text { - Alemtuzumab is FDA approved } \\
\text { for the treatment of B-cell chronic } \\
\text { lymphocytic leukemia. } \\
\text { Alemtuzumab caused dose- } \\
\text { dependent toxicity in a trial in } \\
\text { RA, and is not FDA approved for } \\
\text { use in RA. }\end{array}$ \\
\hline $\mathrm{CD} 27 / \mathrm{CD} 70$ & - $\quad$ Tested in animal model & $\begin{array}{l}\text { A murine anti-CD70 antibody } \\
\text { resulted in improvement in } \\
\text { disease severity and reduction of } \\
\text { autoantibodies in the animal } \\
\text { model of RA. }\end{array}$ \\
\hline
\end{tabular}


Table 3

Toxicities associated with therapeutics designed to target respective receptor/ligand pair in human diseases.

\begin{tabular}{|l|l|l|}
\hline Receptor/ligand targeted & Agent & Observed or anticipated toxicities \\
\hline CD28:CTLA-4/CD80:CD86 & $\begin{array}{l}\text { TGN1412 (anti } \\
\text { CD28 antibody) }\end{array}$ & Cytokine storm and multiorgan failure. \\
\cline { 2 - 3 } & Abatacept & $\begin{array}{l}\text { Minimal side effect profile. Increased risk of infections in combination with } \\
\text { anti-TNF agents. }\end{array}$ \\
\cline { 2 - 3 } & Belatacept & Minimal side effect profile. \\
\hline CD4/MHC Class II & Zanolimab & $\begin{array}{l}\text { Infusion reactions with low-grade fever, flu-like symptoms, unpredictable } \\
\text { occurrence of a skin rash and/or vasculitis, and rapid, prolonged decline of } \\
\text { CD4+ T cells }\end{array}$ \\
\hline CD40/CD40L & BG9588 & $\begin{array}{l}\text { Thromboembolic events in early trials. Further development of this drug is } \\
\text { halted. }\end{array}$ \\
\hline CD2/CD58 & Alefacept & $\begin{array}{l}\text { Lymphopenia, possible increased risk of malignancies, infections, and liver } \\
\text { injury. }\end{array}$ \\
\hline $\begin{array}{l}\text { CD11a-CD18/CD54 (ICAM-1), CD102 } \\
\text { (ICAM-2), CD50 (ICAM-3), CD242 } \\
\text { (ICAM-4), ICAM-5, CD321 (JAM-1) }\end{array}$ & Efalizumab & $\begin{array}{l}\text { Infections, thrombocytopenia, hemolytic anemia, and progressive multifocal } \\
\text { leukoencephalopathy. Withdrawn from the market. }\end{array}$ \\
\hline $\begin{array}{l}\text { CD49d -CD29, CD49d- } \beta 7 \text { integrin/ } \\
\text { VCAM-1, MadCAM-1 }\end{array}$ & Natalizumab & $\begin{array}{l}\text { Progressive multifocal leukoencephalopathy, liver injury, infections, and } \\
\text { hypersensitivity reactions. Withdrawn and reintroduced under a special risk } \\
\text { management plan in patients with MS. }\end{array}$ \\
\hline CD52 & $\begin{array}{l}\text { Cytopenias: serious, including fatal, pancytopenia/marrow hypoplasia, } \\
\text { autoimmune idiopathic thrombocytopenia, autoimmune hemolytic anemia, } \\
\text { infusion reactions, and infections during trails done in RA and multiple } \\
\text { sclerosis. Did not receive FDA approval. }\end{array}$ \\
\hline
\end{tabular}

